\title{
Gender Discrimination and Its Impacts in Macro-Economic Development
}

\author{
Savitri Shrestha, Ph.D. ${ }^{1}$
}

\begin{abstract}
Gender refers to the complex social construction of men's and women's identities. Sex and gender are different. The biological or physical construction is sex, which is created by nature. Gender is purely a social construct.

Gender Equality is a concept that is yet to be materialized. Around the world different individuals and groups of people are marginalized and discriminated on the basis of various factors, but discrimination against women is universal. Due to this, women are not able to use their full potential or assert their rights to live healthy life, and it has a deep impact in economic development.
\end{abstract}

Gender equality is not only matter of human right but also basic of economic development. Gender inequality is a severe obstacle to socio-economic development, human capital development and income generation. Gender inequality is harmful to long term development and growth. Unequal gender will never alone be sufficient for poverty reduction and economic development.

Gender discrimination not only affects females but males as well. The discriminatory practices do not only affect individuals but national economy and world economy as a whole. Due to stereotypical division of work most men are over loaded with economic duties, while women are being limited to household works only. Fifty per cent of the world population is over-loaded with economic duties, while fifty per cent of the brain is underutilized. The economic value of the household work which is done by females is not calculated and reflected in a country's economy. This devalues the effort and work done by females and also is loss for the national economy. Education and development goes together, for a better balance of gender, educational equality is must. Education is key factor to promote human capital, which ensures economic growth. Formal education, trainings, study programs improves the capacity of individuals to live a decent life, which is the basic of development. Gender will never alone be sufficient for development.

Gender equality is not only matter of human right but also basis of economic development. Key words: gender, discrimination, decision, Economic development, macroeconomics 1 Dr. Shrestha is an associate professor of Economics at Patan Campus, TU, Lalitpur. 


\section{Introduction}

"Gender equality is gender justice."

"There is now a shared understanding within the development community that development policies and action that fail to take gender unequal into account and fall to address disparities between males and females will have limited effectiveness and serious cost implications" World bank (2002).

The term gender relation refers to the power relation between women and men which are revealed in a range of practices, ideas, representation, including the division of labor, role and availability of resources between women and men as ascribing different abilities, attitudes, responsibilities, traits, behavioral patterns and so on. Gender relations are both constituted by and help to constitute these practice and ideologies in intersections with other structures of social hierarchy such as class, caste, and race. They may be seen as largely socially constructed (rather than biologically determined) and as variable over time and place (Agrwal, 1996:51).

According to Kamala Vasin "Actually there is a man and woman in each of us, but society does not allow the man in a girl or the woman in a boy to grow."

Biological differences are ones created by nature and the man-made differences are behavior, education, attitudes, of society which are known as social and cultural differences. Gender discrimination was not created by nature. It was completely created by humans. For example, men are considered superior to women, tend to get better paid for the same job, and are considered more intelligent. Nature does not create inequality. It only provides different organs for reproduction. Social and Cultural gender discrimination is the main cause of socio-economic problems and micro and macroeconomic under development.

\section{Gender discrimination and growth}

Discrimination against women and individual due to gender identity including transgender, sexuality, and status is gender discrimination. Discrimination based on gender (sex) is a common civil rights violation that takes many forms, including sexual harassments, domestic violence, sex-selective abortion and unequal pay for women who do the same jobs as men is gender discrimination.

Gender discrimination is creating the complete exclusion of women from the labor market and managerial position. The distortion in the allocation of talent between managerial and unskilled positions and human capital investment are not gender friendly. This type of inequalities reduces the economic development and growth as well. It reduces 
personal income and GDP as well and distorts the allocation of capacity and talent.

"There is a popular notion among many employers who feel that the men have greater responsibility in supporting the family than the women and therefore have a greater right to the job" (Report of the survey of women worker's condition in industry.

Gender discrimination in market reduces the available talent, which had negative impact in econmmy. Women are keeping away from main economic development stream. "while gender discrimination against women in the labor market in developing countries is usually identified with differential wage rates, it is in developing countries that this discrimination appears to take the form of different access to wage employment" (Collier, 1994).

\section{Labour market equilibrium without gender discrimination}

The determinants of growth are the quality of ideas in the economy, managerial talent in production process, productivity of workers, and education of individuals. In case of gender equality, the demand and supply of talent will meet, and the economic development will proceed rapidly.

\section{Labour market equilibrium with gender discrimination in managerial position}

Very less number of women are entrepreneurs. Women are often not hired in decision making posts. Discrimination of labor market creates discrimination in credit market, capital market, and money market, and which directly influences the macroeconomic development. In general, women are told that they are not talented enough to be managers. Fewer women are enrolled in higher education as compared to men. Women also tend to be more engaged in house work. However, women have proved that they are capable of performing tasks at all levels, and capable of taking wise and bold decisions. Increasingly more women prefer to be in labor market as opposed to just doing house work but due to discrimination women are hampered at every stage from education to their careers. They face lots of challenges that they need to overcome. Very few women are at the very top position in the world economy. So half of the world talent is being underutilized. As this is the case with the majority of families, where women could be earning less that their potential, it has a big effect in macroeconomic growth as well.

Gender discrimination acts as a brake on economic development. Women are the extreme minority in big managerial positions. Their talent is underutilized. The lower ratio of female to male significantly reduces the total possible output. 
Research shows that the effects of gender discrimination are quite serious. A ten percent increase in the male to female ratio in managers in India would increase the total output per capita by 2 percent, while $10 \%$ increase in the female to male ratio would increase the total output per capita by 8 percent. So the data shows that gender discrimination affects the macroeconomic growth.

For developed countries, where wage tends to be high, there is no gender discrimination in primary education even in the case of partial discrimination. In the case of developing countries, where wage tends to be lower, there is partial discrimination even in primary education.

The attitude of society towards male and female, social and cultural differences, are not same in every society. Social and cultural definition of male and female is gender which is only created by society. It also creates discrimination between them; this discrimination is causing conflicts between men and women, and creating a big gap between male and female. Gender discrimination is anti-women. So women are facing many obstacles in each field from birth to death.

Gender discrimination is created by male-dominated patriarchal society mostly based on religion. Most of the social laws and judicial laws are also formed on the basis of religion and each religion has created gender discrimination. Almost all religions are created by males; hence all the religions are more male friendly or backed by inequalities.

The entire world is under male domination and they are most powerful in each sector of life, society, and the world. Gender discrimination exists in different forms and varieties in different parts of the world.

\section{Scenario of gender issues and economic growth}

- Clara Jettlin had first raised the voice against unequal salary for equal work in March 8, 1889.

- From then to now many movements has been led by many feminists, even thought the condition is still same (if Rs.100 for men,Rs.77for women)

- Almost all the rules and regulations are based on religious holy book written by men, so they are men friendly; some had been corrected by time to discriminate women or to control them.

- Muslim women are more discriminated.

- In case of Nepal: most of Madheshi women including Muslim women of Tarai are most discriminated by their own community, it is influence of India. 
- Till 100 years ago Chinese men were not punished, if they killed their wives as wives were taken as property of men.

- Most of the cultures are discriminatory.

- Each war has abused women, sexual harassments.

- Women are even not safe in homes and from relatives.

- Each and every woman has to face certain level of sexual harassments once or more in life.

- According to UN report 2014, only in India 70\% women are affected by home harassments.

- In Buddhism, there are 227 rules for men monks and 311 for ladies.

- No country has completely closed, gender pay gap.(Iceland)

- Slovenia: which have the most equal pay had also 3.2\% pay gap.

- Women also haveinferiority complex that they are less capable to men.

- Equal competition between unequal people (education, opportunity, facilities, access in materials) could not said to be fair.

- Before few decades women were not allow to get university education or education.

The story of females is always ignored and never mentioned in our history books and other course books, whereas the stories of males are glorified. This helps to develop a mindset that males are heroes and females only have supportive roles. The ideal female are presented as demure, submissive and obedient never as bold, brave or opinionated.

All the course of studies is made by male, which is gender unfriendly and glorifies male superiority. This creates a perception in both women and men that males are superior and females are not.

Course of studies are also made by man for men, which is not exactly suitable for gender equality.

Same course of study is converting women into secondary category man (impressed with man, so even degree holder women believed man as more wise, brave, intelligent, 
and capable. In this way, women had academic degree but not properly educated, so these types of women or men could not acceptwomen's real skill and capacity (so here is a saying women are against women). This is weakness of our education system and gender unequal course of studies.

These women who try to convert into men will just follow the rules made by man for man, this is creating a gap between women to women (And it is general saying that women are against women).

Uneducated and traditional women just knows the value of son rather than daughter, due to son, mothers are getting respect and being powerful, so they just learned to discriminate daughter or daughter in laws. Most of the women in third countries feel proud to be mother of a boy baby rather than baby girl, because due to baby boy mothers family position and economic and social status used to $b$ high.

Actually even in academic or political field only men type of women can adjust and is accepted by system.

This is creating not only unbalance but alsoviolence, so how can women be safe?

Man base social culture is creating violence and discriminationfrom which women are more affected.

Each and every country each and every women are discriminated in some or other way.

It is creating unbalance in society, in culture, in politics, in economics, history, technology and many more. All total negative impacts are on economic growth.

\section{Impact in economic development}

Due to gender discrimination, women are denied in many decision-making sectors, including social, economic, religious, educational, cultural, and political. They are not getting the chance to get equal opportunities in each sector. So the world politics is in the hand of only $50 \%$ of world population that is male. The other $50 \%$ brain is underutilized.

On the other hand, male are overloaded in economic and family responsibilities. To fulfill the basic requirements of three generations - children, wife, and parents - are loaded to male. Due to this gender discrimination of social nature, even males cannot fully concentrate in career development and decision-making sectors. Due to this, corruption and other illegal activities are rampant. In this way men are also suffering 
from the impact of gender discrimination. Such practices of gender discrimination are harming not only individual families but the entire country and the world.

Mothers are first heroes; your mother is your biggest champion and best friends. If you have your mom behind you can win the world. But mothers are most discriminated, value of their hard work, generation building process for humanity (child care), most valuable household works, basic education for kids, housekeeping, gardening, agriculture, cooking, home management, formulation of family budget and successful implementation, protection of culture and family prestige all are considered as non economicvalueless, free of cost works and unpaid as well. Women are also taken as unfit for national service. The most of the higher decision making powerful post is occupied by male. All most all the world's powerful posts and resources are under control of them, and they are creating the global economic inequalities. One of the most important causes of unequal distribution of wealth or resources (factor of production) is gender discrimination.

- The world's eight richest peoples now have the same wealth as the poorest $50 \%$ (farm reports that just 8 men are now as wealthy as 3.6 billion people).

- In the next decades, 500 people will give 2.1 trillion dollar to their heirs that are more than entire GDP of India.

- The top $1 \%$ won more wealth than the rest of the planet combined.

- From 1988-2011 the income of the poorest 10\% grew by less than $30 \%$,

- The income of the richest $10 \%$ grew by 182 times as much.

- The top $1 \%$ has had an income growth of 300\% (source: Oxfam/colleen, 2016, 2017). All most all these top earners are men. It shows not only economic discrimination but also gender discrimination and less access of women in world resources. This situation is creating not only the resource and power gap but also economic development gap. For the correction of this worse discriminatory inhuman situation action must be taken to strengthen the victims and witness protection mechanism, implement a gender justice frame work and anti discriminationlaws, provision of free legal assistance and ensure speedy access to justice mechanism. The world leaders adopted the sustainable development goals 2015, of 17 goals that are integrated and invisible, goal 5 aims to "Achieve gender equality and empower all women and girls" and include all forms of violence against women and girl. Unpaid household work is a form of exploitation which must be kept in an honourable order and the real value should be given. 
Evaluation of unpaid household, agricultural and livestock works, which are back bone of family economy and family life must be done, the imputation of money value of women ' $\mathrm{s}$ contribution to informal economy must be counted.

The measurement of women's unpaid work is essential for improvement of status of women and formulation of development planning and the determination of real budget; from this the scenario of world economy and the size of budget will be dramatically changed. Only then real and appropriate policies could be lunched, it will helpto reduce gender discrimination and value of mother's effort regarding household economy and national economy. Re distribution of household work load is also a means to reduce gender inequalities.

For better world, gender discrimination should be eliminated and men and women must be equally treated, provided with equal opportunities, rights, and duties.

The attitude of society towards male and female, social or cultural differences, cultural and social discrimination are not same in every society. Since, the concept of gender is man-made, so is gender discrimination. Gender discrimination is present everywhere in the world and in most of the societies and religions.

Due to gender discrimination, women are not included in major decision-making sectors, including social, economic, educational, religious, cultural and political. Due to lack of access in health, education and other basic rights or the right to make decisions of their own lives, women everyday in different parts of the world live a life of humiliation, suffering and domination. Women also lose their lives due to various consequences of gender discrimination, like a lot of young girls lose their lives during childbirth as they are married off at a very young age, and have to say about when they can have children. Even at 21 stcentury, women are being killed in the name of family prestige as honor killing.

\section{Conclusion}

For the whole world to prosper, the gender discrimination must go on gradually diminishing each and every day. There must be equal opportunities for males and females in each sector; and a safe environment for women to flourish and develop their full potential. The education system should be revised so as to acknowledge the true contribution of the female kind in the history and glorify their deeds rather than just showing them in the supportive roles. The education about gender balance and equality 
should be provided to both males and females - only then equality is possible. All forms of violence against females must be ended for the world to walk in the path of development and prosperity.

Equality means lack of discrimination between people on the basis of colour, caste, race, religion, tribe, ethnicity, culture, sex, etc. without any discrimination and without any privileges, providing equal treatment. All humans are equal in their ultimate value. Equal treatment in between unequal persons is also discrimination. All will be equal when the inequality will be ended in basis structure.

Discrimination is not natural as it is a human creation.

Increase the women's occupational limits, actually woman have very limited occupational opportunities and sectors as well. Without any declaration women are kept in a limit of occupation, it is time to identify the limits of women's occupational options, and give them broader options. It is the major problem of modern age, because it is the question of utilization of 50\% world population's brain. Most of women are engaged in household work or middle or low paid works. Only a few women are in high post with high payment. Actually women have no access in factor of production and all resources, no economic and political power, due to this, the social status of women is low too. For elimination of gender inequalities, some special provisions must be taken place.

Provision of education for women in primary and schools secondary, universities, legal, medical, technological etc. are basis of gender equality.

Access of women in each factor of production; land, labor, capital, organization and technology isa must.

Equal access information and administration of rules and laws are very necessary for equality.

Ensure more opportunities for women to enter occupations that have been male preserves and that are higher paid.

Following measures can be taken for elimination of all barriers against gender equality and for Economic growth: 
- To be bold for change and gender equality

- Equal opportunity and utilization of both gender labor

- Equal access in development projects

- Management of changing life style of women (dual responsibility)

- Correction in Under estimation of women's skill and capacity in working and decision making fields

- Transformation of women's traditional household life to professional life State should invest in this field for basic gender equality

- Men should increase household skill.

- A question in capacity only because she is women

- Difference in saying and doing.

- Proper management of labor distribution between men and women, in professional and daily life.

- Women are loaded more than enough in domestic works and men are loaded more than enough in economic and political sector, this situation needs to be balanced.

- Preference and free education for women and marginalized people

- Reform in discriminatory legal systems

- Equal employment and income generating opportunities

- Equal salary for equal jobs

- Evolution of household and agricultural labor of women

- Participation in administrative and political decision

- Strict law against gender based violence

- Preference to female in higher level decision making position

- Mainstreaming gender and social inclusion into all aspects of development and planning processes 
- Awareness raising activities to inform and educate people for gender equality

- Reform in age-old discriminatory social practices

- Various activities for women empowerment

- Social rehabilitation and compensation to the social crime victims

- Special reservation for female in sector until there is equality

More or less women around the world is having problem of gender discrimination, which means half of the world population are under certain level of discrimination. It also means that half of the world brain is underutilization which hampers the overall development of the entire world. Until and unless there is an equal treatment among all genders, it is difficult to imagine a world which is just and progressive. It does not only affect our families and communities but the overall economic progress of the world as a whole.

Gender equality is must for over all development of the entire world.

Gender equality is must for peaceful and just world.

Be bold for change; men and women.

\section{References}

Acharya, B. (2071 BS).Gender and Feminist Studies. Kathmandu: National Book Center

Acharya, B. (2009 AD). Nepal, Newar Ra Nepali Bhasha (Year I, Issue I). Kathmandu: Nepal Sanskrit ParishadPatrika.

Agrawal, C. (2001 AD). Gender Issues. Kathmandu: RatnaPustakBhandar.

Amatya, R. (1997 AD). Changing Socio-economic Profile on an Untouchable Caste (Pode) of SawalBahal at Teku (Unpublished Master's Thesis).Tribhuvan University, Kathmandu.

Bashyal, K. P. (2011 AD). Rights of Dalit, Rights of Dalit as Constitutional Provision in Nepal. Kathmandu: Nepal Law Campus .

Bhasin, K. (1999 AD). What is Gender. Kathmandu: Shri Shakti Publications.

Bista, D. B. (1967 AD). People of Nepal. Kathmandu: Ministry of Information and Broadcasting. 
Collier, P. (1994 AD). Gender Aspects of Labor Allocation During Structural Adjustment: Theoritical Framework and the Africa Experience. Washington: World Bank.

Farrington, J., Ramasut, T., \& Walker, J. (2002 AD). Sustainable Livelihood Approaches in Urban Areas: General Lessons with Illustrations from Indian Cases, London: Overseas Development Institute.

Gellner, D. N., \& Quigley D. (Eds.) (1994 AD), Contested Hieraches: A Collaborative Ethnography of Caste among the Newars of the Kathmandu Valley, Nepal. Oxford, UK: Oxford University Press.

Hawkeshwor, T. M. (1951 AD). Feminist Inquiry. London: Rutgers University Press.

Ojha, B. R. (2059 BS).Contemporary Development Economics. Kathmandu: Taleju Publications.

Rai, C. N. (2002 AD). Sociology. New Delhi: S. Chand Publications.

Shrestha, I. (2002 AD). Women and Governance. Kathmandu: Shristi Shakti.

Shrestha, S. (2063 BS). Nepal Mahila Ra Jana Andolan. Kathmandu: Akshalok Prakashan. 